Bang. J. Anim. Sci. 2009, 38(1\&2) : $132-141$

ISSN 0003-3588

\title{
DUCK REARING SYSTEM IN SOUTHERN COASTAL DISTRICTS OF BANGLADESH
}

\author{
M. M. Rahman ${ }^{1}$, M. J. Khan ${ }^{2}$, S. D. Chowdhury ${ }^{3}$ and M. A. Akbar ${ }^{2}$
}

\begin{abstract}
A study was conducted in two southern coastal districts of Bangladesh (Noakhali and Lakshmipur) to assess the potentiality of the existing duck rearing system of the regions in summer and rainy season. One upazila from each district and three villages from each upazila were selected randomly. Fifty farmers were selected from each village having at least 5 ducks throughout the year. Thus, a total of 300 farmers were selected for this study. The informations were collected by using an interview schedule. The majority of the farmers (39\%) belonged to middle-aged category. Thirty per cent farmers have got primary level of education. About 50 per cent farmers had large family size having an average of 7 persons per family. Twenty seven per cent farmers had small land size with an average of 1.00 ha per household. Sixty one per cent of the respondents considered agriculture as a main occupation. About 99 per cent farmers annually earned Taka 1502.00 from duck rearing. The majority of farmers $(82.25 \%)$ are rearing Desi ducks followed by Crossbred (12\%) and Hybrid (5.75\%). Forty four per cent of the farmers cleaned their duck houses 2-3 times in a month whereas only 11 per cent cleaned their duck houses everyday, 22 per cent once in month, 18 per cent 4-6 times in a month and 5 per cent farmers cleaned their duck houses 7-10 times in a month. About 39 per cent farmers reared ducks under scavenging system with only natural feed resources and 61.5 per cent farmers used supplemental feed, mainly rice polish (118 $\mathrm{g} / \mathrm{bird} /$ day) in summer season. Eighty five per cent farmers in both districts did not use vaccines against duck diseases. However, 10 per cent of the farmers buried their dead ducks somewhere else. It was found from the study that 70 per cent farmers preferred to sell their eggs and ducks to the foria and in local market. It was also observed that duck raising would be more profitable business if the problems related to it could be solved. In terms of profitability, income and employment generation, duck rearing appeared to be a promising sub-sector in agriculture.
\end{abstract}

Key words: Duck, Small farmers, Coastal area, Bangladesh

\section{Introduction}

Poultry keeping is an integral part of the rural farming system that provides family income for the small, marginal and landless poor. The farmers who can not afford to rear cattle and goat can easily rear poultry. It is an important source of family nutrition and almost each and every family has at least 7 to 8 chickens (BBS, 2004). There are 39.08 million ducks in Bangladesh (DLS, 2007) with an average of 4.16 ducks per

\footnotetext{
${ }^{1}$ ADLO, Department of Livestock Services, Government of the People's Republic of Bangladesh

${ }^{2}$ Department of Animal Nutrition, Bangladesh Agricultural University, Mymensingh-2202, Bangladesh

${ }^{3}$ Department of Poultry Science, Bangladesh Agricultural University, Mymensingh-2202, Bangladesh
}

(Received: November 16, 2009) 
household (BBS, 2007), of which 95 per cent are of indigenous (Hoque et al., 2001; Ahmed, 1986). It was found 78 per cent of egg and 86 per cent of poultry meat are produced by the smallholders under scavenging condition (Alam, 1995). Rearing of ducks gives maximum return with minimum cost. Ducks are efficient converter of agricultural by- products; kitchen wastes, seeds, grains, garden left over, insects, green grasses and all other human refusal that would otherwise wasted. Ducks occupy second place in comparison with chicken in producing meat and egg in the country. Ducks are traditionally raised under scavenging (Salahuddin et al., 1991) by the smallholders in coastal and low-lying areas, with little or no feed supplementation.

Duck production in the coastal districts (Noakhali and Lakshmipur) of Bangladesh provides self-employment for landless and small farmers. There is a great potentiality of improving the productivity of ducks in coastal and haors areas through supplementary feeding. Ducks, being an important poultry species, can contribute efficiently in increasing egg and meat production than chicken in the coastal or low lying areas in southern districts. No systematic study has yet been done to assess the potentiality of existing duck rearing system in the coastal districts. The present study generated information on socio-economic profiles of the duck owners, assessed potentiality of existing duck rearing practices, and found out the problems on duck husbandry in the coastal districts of Bangladesh.

\section{Materials and Methods}

The study was conducted in two southern coastal districts; Noakhali and Lakshmipur during summer (March to April, 2003) and rainy season (July to August, 2003) to obtain up-to- date information on duck rearing system. One upazila from each of Noakhali and Lakshmipur district and three villages from each upazila were randomly selected for this study. Fifty farmers from each village were selected randomly. Thus, a total of 300 duck rearers (150 from Noakhali Sadar and 150 from Ramgoti upazila) having at least 5 ducks throughout the year constituted the sample of this survey work. Data were collected through face-to-face interviews using an interview schedule. The data collected in each season of both the districts of Noakhali and Lakshmipur were coded and the average value in each season was used in this study. Means, percentages, standard deviations were used to explain data scientifically.

\section{Results and Discussion}

\section{Socio-economic profile of duck rearers}

The socio-economic profile (Table 1) of the respondents was assessed to ascertain the economic status of the farmers. Majority of the respondents (39\%) belonged to middle aged group (36-50) years. Thirty per cent farmers received primary education and only 9 per cent had higher secondary or above level of education. The literacy rate of 57 per cent recorded seemed to be lower than that of national average of 64.67 per cent (BBS, 2007). A sizable proportion of the respondents $(49.58 \%)$ had large family (more than 7 members). The average family size (6.94 members per family) of the farmers of the study areas was higher than the national average of 4.90 (BBS, 2007). 
Table 1 also indicates that 45 per cent of the farmers had a small area of land ( $0.41 \mathrm{ha})$. Main occupation of the duck rearers was agriculture (61\%) followed by business (17\%), others (15\%) and service (7\%). Farmers (99\%) earned about Tk. 1502.00 annually from duck rearing.

Table 1. Socio-economic characteristics of duck rearing households

\begin{tabular}{|c|c|c|c|c|}
\hline \multirow[b]{2}{*}{ Parameters } & \multicolumn{3}{|c|}{ Farmers (\%) } & \multirow[b]{2}{*}{ Mean \pm SD } \\
\hline & $\begin{array}{c}\text { Noakhali sadar } \\
(n=150)\end{array}$ & $\begin{array}{l}\text { Ramgati } \\
(n=150)\end{array}$ & $\begin{array}{c}\text { Total } \\
(\mathrm{n}=\mathbf{3 0 0})\end{array}$ & \\
\hline \multicolumn{5}{|l|}{ Age (years) } \\
\hline Young (<35 years ) & 42.50 & 29.50 & 36.00 & \multirow{3}{*}{$33.33 \pm 8.44$} \\
\hline Middle (36-50 years) & 37.50 & 40.50 & 39.00 & \\
\hline Old $(>50$ years $)$ & 20.00 & 30.00 & 25.00 & \\
\hline \multicolumn{5}{|l|}{ Education (Number of schooling ) } \\
\hline Illiterate (0) & 21.17 & 26.00 & 23.58 & \multirow{5}{*}{$20.00 \pm 7.57$} \\
\hline Can sign only & 18.83 & 20.00 & 19.41 & \\
\hline Primary (1-5) & 29.50 & 30.83 & 30.17 & \\
\hline Secondary (6-10) & 20.83 & 14.83 & 17.83 & \\
\hline HSC or above $(>10)$ & 9.67 & 8.34 & 9.01 & \\
\hline \multicolumn{5}{|l|}{ Family size (Number) } \\
\hline Small (up to 4) & 29.50 & 18.83 & 24.47 & \multirow{3}{*}{$33.33 \pm 15.97$} \\
\hline Medium (5-6) & 33.50 & 19.00 & 26.25 & \\
\hline Large ( $>6$ members) & 37.00 & 62.17 & 49.58 & \\
\hline \multicolumn{5}{|l|}{ Farm size (hectare) } \\
\hline Landless (0-0.19 ha) & 26.50 & 23.00 & 24.75 & \multirow{5}{*}{$20.00 \pm 8.98$} \\
\hline Marginal $(0.20-0.40 \mathrm{ha})$ & 19.00 & 20.50 & 19.75 & \\
\hline Small $(0.41-1.00 \mathrm{ha})$ & 35.00 & 19.50 & 27.25 & \\
\hline Medium (1.01-3.03 ha) & 18.00 & 25.50 & 21.75 & \\
\hline Large $(>3.03 \mathrm{ha})$ & 1.50 & 11.50 & 6.50 & \\
\hline \multicolumn{5}{|l|}{ Occupation (Type) } \\
\hline Agriculture & 59.50 & 62.50 & 61.00 & \multirow{4}{*}{$25.00 \pm 22.76$} \\
\hline Service & 8.50 & 5.50 & 7.00 & \\
\hline Business & 20.50 & 13.50 & 17.00 & \\
\hline Others & 11.50 & 18.50 & 15.00 & \\
\hline \multicolumn{5}{|l|}{ Annual income (Taka) } \\
\hline Duck & 1623 & 1380 & 1501.50 & $1501.50 \pm 171.83$ \\
\hline$\%$ of farmers involved in duck rearing & 98 & 99 & 98.5 & $98.5 \pm 0.71$ \\
\hline
\end{tabular}

\section{Duck rearing practice}

Most of duck house (65.5\%) are made of tin and wood (Table 2). Most duck owners (93.5\%) kept ducks in separate house at a corner of the premises with sufficient ventilation. Rest (6.5\%) kept ducks in their bed room. The majority of the farmers $(95.7 \%)$ did not take special care for ducklings due to lack of knowledge and training. Most of the farmers (82.25\%) were involved in rearing Desi ducks followed by 
Bang. J. Anim. Sci. 2009, 38(1\&2)

Crossbred (12\%) and Hybrid (5.75\%). Farmers mainly (67.5\%) used ponds as the scavenging venue for duck. Forty three per cent respondents used to allow their ducks to scavenge 9 hours a day. This is in well agreement with the observation of Fouzder et al. (1999) and Huque et al. (1993). Very small number of farmers (2.25\%) used sawdust and sand as litter. About 45 per cent of duck owners cleaned their duck houses 2-3 times in a month, whereas only 10.50 per cent cleaned their duck houses every day.

Table 2. Duck rearing practices by respondents

\begin{tabular}{|c|c|c|c|c|}
\hline \multirow[b]{2}{*}{ Parameters } & \multicolumn{4}{|c|}{ Farmers (\%) } \\
\hline & $\begin{array}{l}\text { Noakhali sadar } \\
\quad(n=150)\end{array}$ & $\begin{array}{l}\text { Ramgati } \\
(n=150)\end{array}$ & $\begin{array}{c}\text { Total } \\
(n=300)\end{array}$ & Mean \pm SD \\
\hline \multicolumn{5}{|c|}{ Materials to construct duck house } \\
\hline Tin and wood & 63.50 & 67.50 & 65.50 & $25.00 \pm 25.47$ \\
\hline Straw and bamboo & 7.50 & 13.00 & 10.25 & \\
\hline Bamboo & 20.00 & 15.00 & 17.50 & \\
\hline Soil and others & 9.00 & 4.50 & 6.75 & \\
\hline \multicolumn{5}{|l|}{ Location of duck house } \\
\hline Premises & 91.50 & 95.50 & 93.50 & $50.00 \pm 50.28$ \\
\hline Bed room & 8.50 & 4.50 & 6.50 & \\
\hline Special care for ducklings & 5.30 & 3.30 & 4.30 & $4.30 \pm 1.41$ \\
\hline \multicolumn{5}{|l|}{ Breeds } \\
\hline Desi & 80.00 & 84.50 & 82.25 & $33.33 \pm 38.04$ \\
\hline Crossbred & 12.50 & 11.50 & 12.00 & \\
\hline Hybrid & 7.50 & 4.00 & 5.75 & \\
\hline \multicolumn{5}{|l|}{ Places for scavenging } \\
\hline Pond & 70.00 & 65.00 & 67.50 & $28.57 \pm 27.20$ \\
\hline Canal & 21.50 & 19.00 & 20.25 & \\
\hline River & 0.00 & 6.50 & 3.25 & \\
\hline Agricultural field & 8.50 & 9.50 & 9.00 & \\
\hline \multicolumn{5}{|l|}{ Scavenging period } \\
\hline 8 hr/day & 32.00 & 24.00 & 28.00 & $33.33 \pm 8.13$ \\
\hline 9 hr/day & 40.50 & 45.50 & 43.00 & \\
\hline $10 \mathrm{hr} /$ day & 27.50 & 30.50 & 29.00 & \\
\hline \multicolumn{5}{|l|}{ Litter used } \\
\hline Ash & 17.50 & 14.50 & 16.00 & $9.125 \pm 8.10$ \\
\hline Sawdust & 3.50 & 0.00 & 1.75 & \\
\hline Sand & 1.00 & 0.00 & 0.50 & \\
\hline \multicolumn{5}{|c|}{ Cleaning of house time/month) } \\
\hline Once & 20.00 & 23.50 & 21.75 & $20.00 \pm 14.48$ \\
\hline $2-3$ & 42.50 & 46.50 & 44.50 & \\
\hline $4-6$ & 22.50 & 13.50 & 18.00 & \\
\hline $7-10$ & 5.50 & 5.00 & 5.25 & \\
\hline Everyday & 9.50 & 11.50 & 10.50 & \\
\hline
\end{tabular}




\section{Feeding and management practice}

Among farmers, 38.50 per cent did not supply additional feed to their ducks. Ducks were reared under scavenging condition (with only natural feed resources) during rainy season. Whereas, 62 per cent farmers gave supplemental feeding to their ducks amounting to $118 \mathrm{~g}$ per day to maximize egg production. The main components of supplemental feeds were rice polish, a mixture of rice polish and broken rice and a mixture of rice polish and wheat bran. About 44 per cent farmers supplemented their ducks with only rice polish. This finding closely agreed with Hoque et al., 2001. They reported that farmers of Sylhet basin supplied $117 \mathrm{~g}$ additional feed/duck/day during dry period. About 17 per cent farmers provided supplemental feed from their own homegrown ingredients. Approximately 38 per cent respondents purchased feed ingredients from the local market while 45.75 per cent used supplemental feeds from both sources (Table 3). About 51 per cent of the duck rearing households thrown away feed refusals to the pond or out side whereas a few farmers (27\%) mixed feed refusals with new feed and rest of the farmers (22.5\%) reported that they did not have any feed refusal. It was also observed that 53.5 per cent respondents in all areas used tube well water as a source of drinking water for ducks (Table 3).

Table 3. Duck feeding and management practices

\begin{tabular}{|c|c|c|c|c|}
\hline \multirow[b]{2}{*}{ Parameters } & \multicolumn{4}{|c|}{ Farmers (\%) } \\
\hline & $\begin{array}{l}\text { Noakhali sadar } \\
(n=150)\end{array}$ & $\begin{array}{l}\text { Ramgati } \\
(\mathrm{n}=150)\end{array}$ & $\begin{array}{c}\text { Total } \\
(\mathrm{n}=\mathbf{3 0 0})\end{array}$ & Mean \pm SD \\
\hline \multicolumn{5}{|l|}{ Feed supply (Summer season) } \\
\hline Natural (scavenging) & 37.00 & 40.00 & 38.50 & $50.00 \pm 13.39$ \\
\hline Supplementation & 63.00 & 60.00 & 61.50 & \\
\hline \multicolumn{5}{|l|}{ Component of supplementation } \\
\hline Rice polish & 42.70 & 45.00 & 43.85 & $17.95 \pm 20.08$ \\
\hline Mixture of rice polish and broken rice & 5.70 & 4.70 & 5.20 & \\
\hline Mixture of rice polish and wheat bran & 5.30 & 4.30 & 4.80 & \\
\hline \multicolumn{5}{|l|}{ Sources of supplemental feed } \\
\hline Own source & 15.50 & 17.50 & 16.50 & $33.33 \pm 13.56$ \\
\hline Purchase & 39.00 & 36.50 & 37.75 & \\
\hline Both (own source + purchase) & 45.50 & 46.00 & 45.75 & \\
\hline \multicolumn{5}{|l|}{ Fate of refusal feed } \\
\hline Thrown away & 54.00 & 47.00 & 50.50 & $33.33 \pm 14.123$ \\
\hline Mixed with new feed & 29.00 & 25.00 & 27.00 & \\
\hline No residue & 17.00 & 28.00 & 22.50 & \\
\hline \multicolumn{5}{|l|}{ Sources of drinking water } \\
\hline Pond & 51.00 & 42.00 & 46.50 & $50.00 \pm 6.58$ \\
\hline Tube well & 49.00 & 58.00 & 53.50 & \\
\hline
\end{tabular}

\section{Prevalence of duck diseases and their prophylactic measures}

Duck plague and duck cholera were the common diseases of ducks reported in the study areas. Among two seasons, most of the outbreak of diseases was found in summer (34.18\%) followed by rainy season $(2.25 \%)$. The high incidence of disease during summer may be due to poor nutritional status. In case of health care and 
management practices of ducks, most of the respondents (92.75\%) followed traditional method. Majority of the farmers $(85.5 \%)$ did not use vaccines against the diseases of ducks for unavailability. This result is well agreement with the findings of Rithamber et al. (1986, Tu (1995) and Seri Masrah (1996). About 74.37 per cent farmers used apparently sick ducks for their family consumption rather than attempting to give treatment. Only 9.75 per cent farmers buried dead ducks and the rest (90.25\%) farmers had thrown dead ducks somewhere else which definitely created environmental hazards (Table 4).

Table 4. Prevalence of duck diseases and prophylactic measures

\begin{tabular}{|c|c|c|c|c|}
\hline \multirow[b]{2}{*}{ Health care practices } & \multicolumn{4}{|c|}{ Farmers (\%) } \\
\hline & \begin{tabular}{|c|} 
Noakhali sadar \\
$(n=150)$
\end{tabular} & $\begin{array}{l}\text { Ramgati } \\
(\mathrm{n}=150)\end{array}$ & $\begin{array}{c}\text { Total } \\
(n=300)\end{array}$ & Mean \pm SD \\
\hline \multicolumn{5}{|l|}{ Prevalence of diseases } \\
\hline Duck plague & 100.00 & 100.00 & 100.00 & $100.00 \pm 0.00$ \\
\hline Duck cholera & 100.00 & 100.00 & 100.00 & \\
\hline \multicolumn{5}{|l|}{ Season wise disease } \\
\hline Rainy & 2.87 & 1.63 & 2.25 & $18.22 \pm 18.57$ \\
\hline Summer & 31.50 & 36.87 & 34.18 & \\
\hline \multicolumn{5}{|l|}{ Mode of treatment } \\
\hline Traditional & 91.00 & 94.50 & 92.75 & $50.00 \pm 49.40$ \\
\hline Modern & 9.00 & 5.50 & 7.25 & \\
\hline Vaccination & 10.00 & 19.00 & 14.50 & $14.5 \pm 6.36$ \\
\hline \multicolumn{5}{|l|}{ Fate of diseased duck } \\
\hline Isolation and medication & 6.75 & 7.75 & 7.25 & $25.00 \pm 30.54$ \\
\hline Sell to market & 12.50 & 9.50 & 11.00 & \\
\hline Slaughter & 72.75 & 76.00 & 74.37 & \\
\hline Done nothing & 8.00 & 6.75 & 7.38 & \\
\hline \multicolumn{5}{|l|}{ Disposal of dead duck } \\
\hline Thrown out & 89.50 & 91.00 & 90.25 & $50.00 \pm 46.48$ \\
\hline Buried & 10.50 & 9.00 & 9.75 & \\
\hline
\end{tabular}

\section{Duck egg production}

It is evident from Table 5 that Desi ducks attained their sexual maturity at 26-27 weeks of age. These findings were more or less similar with the results of Hoque et al. (2001) and Islam et al. (2003). They reported that indigenous ducks reached sexual maturity at 23-25.5 weeks of age. The present findings contradict Rithamber et al. (1986) and Mahanta et al. (2001), who found that ducks attained sexual maturity at 32 weeks of age. Annual egg production (77.15) of scavenging Desi ducks obtained partially agree with Salam and Bulbul (1983) and Huque and Ukil (1994). They reported a range of 6091 eggs/year/duck. However, slightly higher annual egg production (89 eggs/year/duck) of local duck in haor areas was reported by Fouzder et al. (1999). It was observed from the study that average egg weight of duck was $59.31 \mathrm{~g}$. The observation in this study was closely related with the findings of Rithamber et al. (1986) and Das and Hoq (2000). 
They found that egg weight of ducks ranged between 56 and $60 \mathrm{~g}$. The hatchability per cent of eggs was 79 which is almost similar with the results of Islam et al. (2002), Ravindran et al. (1984) and Alam and Hossaion (1989).

Table 5. Duck egg production

\begin{tabular}{|c|c|c|c|c|}
\hline \multirow[b]{2}{*}{ Parameters } & \multicolumn{3}{|c|}{ Farmers (\%) } & \multirow[b]{2}{*}{ Mean \pm SD } \\
\hline & $\begin{array}{l}\text { Noakhali sadar } \\
\quad(n=150)\end{array}$ & $\begin{array}{l}\text { Ramgati } \\
(n=150)\end{array}$ & $\begin{array}{c}\text { Total } \\
(n=300)\end{array}$ & \\
\hline Age at maturity (weeks) & 26.53 & 26.73 & 26.63 & $26.63 \pm 0.14$ \\
\hline Annual egg production (Number/duck) & 79.62 & 74.68 & 77.15 & $77.15 \pm 3.49$ \\
\hline Egg weight (g/egg) & 59.77 & 58.85 & 59.31 & $59.31 \pm 0.65$ \\
\hline Broodiness (\%) & 25.00 & 25.00 & 25.00 & $25.00 \pm 0.00$ \\
\hline Hatchability (\%) & 77.00 & 81.00 & 79.00 & $79.00 \pm 2.83$ \\
\hline
\end{tabular}

\section{Marketing of eggs and ducks}

It is revealed from Table 6 that 70 per cent duck farmers preferred to sell their eggs to the foria and in local market. This observation is consistent with the findings of Hoque et al. (2001) and Islam et al. (2002).

Table 6. Marketing channels of eggs and ducks by farmers

\begin{tabular}{|l|c|c|c|c|}
\hline \multirow{2}{*}{ Extent of marketing } & \multicolumn{3}{|c|}{ Farmers (\%) } & \multirow{2}{*}{ Mean \pm SD } \\
\cline { 2 - 4 } & $\begin{array}{c}\text { Noakhali sadar } \\
(\mathbf{n = 1 5 0 )}\end{array}$ & $\begin{array}{c}\text { Ramgati } \\
(\mathbf{n = 1 5 0 )}\end{array}$ & $\begin{array}{c}\text { Total } \\
(\mathbf{n = 3 0 0})\end{array}$ & \\
\hline Local market and foria & 70.67 & 69.33 & 70.00 & $25.00 \pm 27.91$ \\
Neighbour, foria and market & 10.66 & 14.67 & 12.67 & \\
Neighbour and foria & 6.00 & 8.00 & 7.00 & \\
Local market and others & 12.67 & 8.00 & 10.33 & \\
\hline
\end{tabular}

\section{Constraints faced by farmers in raising ducks}

\section{Technical}

It is evident from Table 7 that 94 per cent farmers did not get day-old-ducklings at appropriate time. Similarly, 99 per cent farmers had no training on duck rearing. Ninety one per cent farmers identified interruption of electricity as a serious problem. Poor knowledge on duck housing (48\%) and management $(64.50 \%)$ were the significant problems faced by the farmers.

\section{Feed related problem}

Higher prices of quality feed (97\%) appeared to be a major constraints to farmers. Scarcity of scavenging feed in summer season (91\%) and inadequate knowledge on duck nutrition (89\%) are the constraints mentioned by the farmers. 
Bang. J. Anim. Sci. 2009, 38(1\&2)

Table 7. Constraints faced by farmers in raising ducks

\begin{tabular}{|c|c|c|c|c|}
\hline \multirow[b]{2}{*}{ Parameters } & \multicolumn{3}{|c|}{ Farmers (\%) } & \multirow[b]{2}{*}{ Mean \pm SD } \\
\hline & $\begin{array}{l}\text { Noakhali sadar } \\
(n=150)\end{array}$ & $\begin{array}{l}\text { Ramgati } \\
(\mathrm{n}=150)\end{array}$ & $\begin{array}{c}\text { Total } \\
(n=300)\end{array}$ & \\
\hline \multicolumn{5}{|l|}{ Technical } \\
\hline $\begin{array}{l}\text { Un-availability of day-old duckling at } \\
\text { proper time }\end{array}$ & 95.00 & 93.00 & 94.00 & $79.27 \pm 20.78$ \\
\hline Interruption of electricity & 90.00 & 92.00 & 91.00 & \\
\hline Poor knowledge about duck housing & 47.00 & 49.000 & 48.00 & \\
\hline Lack of training on duck rearing & 98.33 & 99.33 & 98.83 & \\
\hline Poor Management & 62.00 & 67.00 & 64.50 & \\
\hline \multicolumn{5}{|l|}{ Feed related } \\
\hline Scarcity of feed in summer season & 91.00 & 90.00 & 90.50 & $89.00 \pm 6.76$ \\
\hline Unavailability of quality feed & 78.00 & 82.00 & 80.00 & \\
\hline Inadequate knowledge on duck nutrition & 85.00 & 93.00 & 89.00 & \\
\hline Higher price of quality feed & 96.00 & 97.00 & 96.50 & \\
\hline \multicolumn{5}{|l|}{ Health care } \\
\hline Outbreak of diseases & 99.67 & 100.00 & 99.83 & $94.29 \pm 5.27$ \\
\hline $\begin{array}{l}\text { Insufficient preventive health care and } \\
\text { lack of knowledge about infectious and } \\
\text { parasitic diseases }\end{array}$ & 89.00 & 93.00 & 91.00 & \\
\hline $\begin{array}{l}\text { Unavailability of veterinary medicines and } \\
\text { services }\end{array}$ & 97.33 & 98.67 & 98.00 & \\
\hline $\begin{array}{l}\text { Higher price of veterinary dregs and } \\
\text { medicines }\end{array}$ & 89.67 & 87.00 & 88.33 & \\
\hline \multicolumn{5}{|l|}{ Marketing } \\
\hline $\begin{array}{l}\text { Propaganda behind duck meat and egg } \\
\text { consumption }\end{array}$ & 68.00 & 63.00 & 65.50 & $81.00 \pm 12.51$ \\
\hline Higher price of day-old ducklings & 93.00 & 91.00 & 92.00 & \\
\hline Lower price of meat and egg & 87.00 & 84.00 & 85.50 & \\
\hline \multicolumn{5}{|l|}{ Social } \\
\hline Low status of duck rearers & 48.00 & 41.00 & 44.50 & $30.13 \pm 12.35$ \\
\hline Theft & 35.50 & 39.00 & 37.25 & \\
\hline Threat to predators & 21.00 & 25.00 & 23.00 & \\
\hline Risk of damaging paddy field & 15.50 & 16.00 & 15.75 & \\
\hline
\end{tabular}

\section{Heath care}

It is evident from Table 7 that almost all duck owners (100\%) reported that the outbreak of diseases and unavailability of veterinary services (98\%) were two remarkable problems for the development of duck farms. Insufficient health care and lack of knowledge on infectious and parasitic diseases (91\%) and higher price of drugs and vaccines (88\%) were also the constraints in rearing ducks. 


\section{Marketing}

The most acute problems of duck rearing were lower price of meat and eggs (86\%) and higher price of day-old-ducklings (92\%). About 66 per cent farmers faced lower consumer demand for duck meat and eggs (Table 7).

\section{Social}

In the study areas farmers thought that duck rearing business was not an honorable occupation. Problems like theft (37\%), threat of predators $(23 \%)$ and risk of damaging paddy field (16\%) were identified as a social problem in the study areas. However, it was observed that 85 per cent of the duck owners were interested to rear more ducks ranging from 50 to 100 .

\section{Acknowledgements}

The authors are highly grateful to DANIDA-DLS which project for financing the research project under which the present study was conducted. The authors are also grateful to the farmers involved in duck rearing who provided valuable informations related to this study.

\section{Literature Cited}

Ahmed, S. 1986. Duck Production in Bangladesh. In: Duck Production Science and World Practice. Farrell, D.J. and Stapleton, P (Eds) University of New England, Armidale, Australia, pp. 342-350.

Alam, A. B. M. M. and Hossain, M. B. 1989. Hatchability of egg and suvivability of Khaki Campbell under farmer's condition. Bang. J. An. Sci. 18 (1-2): 105-108.

Alam, J. 1995. Livestock resources in Bangladesh. Present status and future potential. $1^{\text {st }}$ edition. The University Press Limited. pp. 2-7, 24-29.

BBS. 2004. Bangladesh Bureau of Statistics. Statistical Year book of Bangladesh. Ministry of Planning, Government of the People's Republic of Bangladesh, Dhaka. p. 50.

BBS. 2007. Bangladesh Bureau of Statistics. Statistical Year book of Bangladesh. Ministry of Planning, Government of the People's Republic of Bangladesh, Dhaka. pp. 33-34.

Das, G. B. and Hoq, M. E. 2000. Performance of Khaki Campbell, Jinding and Khaki Campbell $\times$ Indigenous ducks in integrated fish-cum-duck farming system. Bang. J. An. Sci. 29(1-2): 111-117.

DLS. 2007. Annual Progress Report. Department of Livestock Services. Farm gate, Dhaka.

Fouzder, S. K., Khaleque, M. A. and Alam, A. B. M. M. 1999. Evaluation of bio-economic performance of duck farming in Haor area. Bangladesh J. Train and Devt. 12 (1 \& 2): 93-98.

Hoque, K. S., Sarker, M. S. K., Huque, Q. M. E. and Islam, M. N. 2001. Duck production in the Sylhet basin of Bangladesh-Prospects and problems. Paper presented in the seminar and International Poultry show organized by the World's Poultry Science AssociationBangladesh Branch at IDB Bhaban, February 16-17, pp. 40-51. 
Bang. J. Anim. Sci. 2009, 38(1\&2)

Huque, Q. M. E. and Ukil, M. A. 1994. Existing poultry production and utilization system in the traditional villages in Bangladesh. Bangladesh J. Train. and Devt. 7(1): 35-43.

Huque, Q. M. E., Ukil, M. A. and Hossain, M. J. 1993. Supplementary feeding for laying ducks under scavenging condition. Bangladesh J. Live. Res. 1(1): 57-62.

Islam, M. N., Huque, Q. M. E., Uddin, M. S. and Sarker, M. S. K. 2003. Potentiality of native genotypes of Ducks. Proceedings of Third International Poultry Show and Seminar, Organized by World's Poultry Science Association, Bangladesh Branch, Dhaka. pp. 259-270.

Islam, R., Mahanta, J. D., Barua, N. and Zaman, G. 2002. Duck farming in North-Eastern India (Assam). World's Poult. Sci. J. 58(4 ): 567-572.

Mahanta, J. D., Sapcota, D., Mili, D. C. and Chakravorty, A. 2001. A survey on duck farming in Lakhimpur and Dhemaji distircts of Assam. Indian Vet. J. 78(6): 531-532.

Ravindran, T. K., Venugopalan, C. K. and Ramkrishnan, A. 1984. A survey in the status of duck farming in Kerala state. Indian J. Poult. Sci. 19 (2): 77-80.

Rithamber, V., Reddy, R. and Rao, P. V. 1986. A survey study of duck farming and hatcheries in Andhra Pradesh. Indian J. Poult. Sci. 21(3): 180-185.

Salahuddin, M., Barua, A., Rashid, N. and Howlider, M. A. R. 1991. A study on the relationship of egg weight with fertility and hatchability of Desi ducks. Poultry Guide. 28(3): 34-37.

Salam, M. A. and Bulbul, S. M. 1983. A comparative study of performance of Khaki Campbell and Indian Runner ducks under Bangladesh Agricultural University farm condition. Bang. J. An. Sci. 12(1-2): 39-48.

Seri Masrah, M. S. 1996. Malaysia-country report. Proceedings, Ninth Asian Science and Poultry Diseases and their control. pp. 23-29.

Tu, T. D. 1995. Poultry diseases and control in Vietnam-an overview. Proceedings of First Vietnamese-Hungarian Workshop on Small Animal Production for the Development of Sustainable Integrated Farm. pp. 143-147. 